\title{
Glutathione S-transferase polymorphisms and risk of ovarian cancer: A HuGE review
}

Steven S. Coughlin, PhD, and Ingrid J. Hall, PhD, MPH

\begin{abstract}
Glutathione S-transferases (GSTs) catalyze the conjugation of glutathione to numerous potentially genotoxic compounds. The GSTM1 gene codes for the enzyme glutathione S-transferase-mu, the GSTT1 gene codes for the enzyme glutathione S-transferase-theta, and the GSTP1 gene codes for the enzyme glutathione S-transferase-pi. GSTM1 is polymorphically expressed, and three alleles have been identified (GSTM1-0, GSTM1a, and GSTM1b). Two functionally different genotypes at the GSTT1 locus have been described. Individuals with homozygous deletions of GSTM or GSTT have reduced or no glutathione S-transferase activity and therefore may be unable to eliminate electrophilic carcinogens as efficiently. However, results of epidemiologic studies do not confirm associations between GSTM1, GSTT1, and GSTP1 and epithelial ovarian cancer. Genet Med 2002:4(4):250-257.
\end{abstract}

Key Words: epidemiology, glutathione S-transferases, GSTM1, GSTP1, GSTT1, ovarian cancer

An increasing number of epidemiologic studies have examined associations between GSTM1, GSTT1, and GSTP1 and epithelial ovarian cancer. Associations with GSTM1, GSTT1, and GSTP1 genotype have not been observed in most studies, many of which have had small sample sizes or other design limitations. However, GSTM1 null genotype was found to be more frequent among cases than controls in a recent study of epithelial ovarian cancer that included more subjects (59\% vs. $49 \%, \mathrm{OR}=1.5,95 \%$ CI $1.1-2.1) .^{54}$

Results from this and one other recent case-control study suggest that deletion of GSTM1 may increase the risk of specific histological subtypes of ovarian cancer (endometrioid and clear cell).

This Human Genome Epidemiology Network (HUGE Net) review critically evaluates published studies of these associations and offers suggestions for future research.

\section{GENE}

Glutathione $S$-transferases (GSTs) catalyze the conjugation of glutathione to numerous potentially genotoxic compounds, including aliphatic aromatic heterocyclic radicals, epoxides, and arene oxides. ${ }^{1-3}$ The enzymes detoxify carcinogenic polycyclic aromatic hydrocarbons and conjugate isothiocyanates. Six families of enzymes have been classified as alpha, mu, pi, theta, zeta, and omega. Glutathione $S$-transferase-mu (GSTM1), glutathione S-transferase-theta (GSTT1), and glu-

From the Epidemiology and Health Services Research Branch, Division of Cancer Prevention and Control, Centers for Disease Control and Prevention, Atlanta, Georgia.

Steven S. Coughlin, PhD, Epidemiology and Health Services Research Branch, Division of Cancer Prevention and Control, Centers for Disease Control and Prevention, 4770 Buford Highway NE (K-55), Atlanta, GA 30341.

Received: February 8, 2002.

Accepted: April 23, 2002. tathione $S$-transferase-pi (GSTP1) have been studied most. ${ }^{3}$ The GSTM1 gene, which is located on chromosome 1p13.3, codes for the enzyme glutathione $S$-transferase-mu. The GSTT1 gene codes for the enzyme glutathione $S$-transferasetheta; the GSTT1 gene is located on chromosome 22q11.2. The GSTP1 gene codes for the enzyme glutathione $S$-transferase-pi and is located on chromosome 11q13. GSTA1 and GSTA2, the two major glutathione $S$-transferase-alpha genes, are mentioned less frequently in the literature and are located on chromosome $6 \mathrm{p} 12$. The GSTZ1 gene that encodes glutathione $S$ transferase-zeta was mapped to chromosome 14q24.3.4,5 The glutathione $S$-transferase-omega (GSTO1) gene was recently characterized. ${ }^{6}$ The GSTs have broad and overlapping substrate specificities that have been previously reviewed. ${ }^{7}$

\section{GENE VARIANTS}

GSTM1 is polymorphically expressed, and three alleles have been identified: GSTM1-0, GSTM1a, and GSTM1b. ${ }^{3}$ There is no evidence of functional differences between GSTM1a and GSTM1b, which differ by a substitution in one base pair. ${ }^{8}$ The GSTT1 locus has a single allele that is either present or absent (deleted). Two functionally different genotypes at the GSTT1 locus have been described. The first, GSTT1-0, is a homozygous deletion. The second, GSTT1-1, comprises genotypes with one or two functional alleles present. There are also three variant alleles of GSTP1. GSTP1 $a$ and GSTP1 $b$ differ by an A to G substitution at codon 105 that exchanges isoleucine for valine. GSTP1c varies from the "a" allele by the substitution of valine for alanine at codon 114. Individuals with homozygous deletions of GSTM or GSTT have reduced or no glutathione $S$-transferase activity and therefore may be unable to eliminate electrophilic carcinogens as efficiently. This may increase the risk of somatic mutations leading to tumor formation. Evidence is lacking on whether heterozygosity in either GSTM1 or 
GSTT1 affects gene function. ${ }^{8}$ An analysis of functional differences in the GSTP1 variant proteins was performed by evaluating the ability of recombinant GSTP1 proteins to catalyze the conjugation of glutathione with 1-chloro-2,4-dinitrobenzene, a universal GST substrate. Results showed that catalytic activity was 3- to 4-fold higher for the GSTP1a variant than for either GSTP1b or GSTP1c. ${ }^{9}$ This indicates that enzyme activity is significantly reduced in individuals who carry the valine allele.

Cotton et al. ${ }^{8}$ summarized information on the frequency of homozygosity and heterozygosity of GSTM1 and GSTT1 allelic variants in different populations and ethnic groups; updated information on the frequency of these variants was provided by Geisler and Olshan. ${ }^{10}$ Both of these articles are posted on the Centers for Disease Control website on the Internet. ${ }^{8,10}$ The frequency of the GSTM1 null genotype ranges from $23 \%$ to $48 \%$ in African populations, $33 \%$ to $63 \%$ in Asian populations, $39 \%$ to $62 \%$ in European populations, and $23 \%$ to $62 \%$ in U.S. populations. ${ }^{8}$ In selected U.S. populations, the frequency of the GSTM1 null genotype ranges from $23 \%$ to $41 \%$ in AfricanAmericans, $35 \%$ to $62 \%$ in whites, $32 \%$ to $53 \%$ in Asians, and $40 \%$ to $53 \%$ in Mexican-Americans.

The frequency of the GSTT1 null genotype ranges from 15\% to $26 \%$ in African populations, $16 \%$ to $64 \%$ in Asian populations, and $10 \%$ to $21 \%$ in European populations. ${ }^{8}$ In U.S. populations, the frequency of the GSTT1 null genotype ranges from $22 \%$ to $29 \%$ in African-Americans, $15 \%$ to $27 \%$ in whites, and $10 \%$ to $12 \%$ in Mexican-Americans.

To obtain information on the frequency of homozygosity and heterozygosity of GSTP1 allelic variants in different populations and ethnic groups, we searched MEDLINE by using the MeSH heading "glutathione transferase" and the text word "GSTP1." Reference lists were also reviewed from published articles. Papers written in English and published between January 1993 and March 2001 were reviewed. The majority of the studies reviewed, including studies reporting genotype frequencies among individuals without cancer, had a case-control design. ${ }^{11-33}$ The frequencies for polymorphisms in exon 5 and exon 6 of the GSTP1 gene among control individuals are summarized in Table 1. Studies have been conducted on all continents with the exception of Africa and South America; only two studies have been conducted in the United States. The frequency of the homozygous wildtype genotype at exon 5 ranges from $39 \%$ to $59 \%$ in whites, $52 \%$ to $93 \%$ in Asians, and $35 \%$ in the single study involving African-Americans. The heterozygous genotype ranged from $30 \%$ to $50 \%$ among whites, $24 \%$ to $44 \%$ among Asians, and $46 \%$ among African-Americans. The homozygous mutant genotype ranged from $4 \%$ to $16 \%$ among whites, $4 \%$ to $5 \%$ among Asians, and $19 \%$ for African-Americans. For the exon 6 polymorphism, the frequency of the homozygous wildtype genotype ranged from $75 \%$ to $85 \%$ among whites, $98 \%$ to $100 \%$ among Asians, and 95\% among African-Americans. Heterozygous genotypes ranged from $15 \%$ to $25 \%$ among whites, $0 \%$ to $2 \%$ among Asians, and 5\% among African-Americans. The homozygous mutant genotype was only found among persons from India $(2 \%)$.

\section{DISEASE}

Ovarian cancer is the sixth most common cancer among U.S. women. ${ }^{34}$ An estimated 23,300 new cases will be diagnosed in 2002 and an estimated 13,900 U.S. women will die from the disease this year. Based upon SEER data for the period 1988 to 1992, ovarian cancer incidence rates among U.S. women were highest among American-Indian women (ageadjusted rate 17.5 per 100,000 ), followed by non-Hispanic white (age-adjusted rate 15.8 per 100,000), Vietnamese, white Hispanic, and Hawaiian women. ${ }^{35}$ Rates were intermediate among African-American women (age-adjusted rate $10.2 \mathrm{per}$ $100,000)$ and lowest among Korean and Chinese women in the United States over that time period. Worldwide, the highest ovarian cancer incidence rates are found in white women in Europe (especially Scandinavian countries), Israel, and North America. Rates among women in Central and South America and in Asia (including Japan) are relatively low. ${ }^{36}$

The majority of malignant ovarian tumors originate in epithelial cells. More is known about the descriptive epidemiology and etiology of epithelial ovarian cancer than germ cell or sex cord-stromal (follicular) tumors. ${ }^{36}$ The most common type of epithelial tumors is serous carcinoma (which comprises about $40 \%$ of epithelial ovarian cancers), followed by mucinous carcinomas $(6-16 \%)$, endometrioid carcinomas (15-25\%), and clear cell carcinomas $(5-11 \%){ }^{37}$

Established risk factors for epithelial ovarian cancer include age, family history of ovarian cancer, personal history of endometrial or breast cancer, and nulliparity. ${ }^{36}$ Other risk factors that have been less consistently associated with ovarian cancer include history of infertility, use of infertility drugs, early age of menarche, late menopause, and use of talc. ${ }^{36}$ History of one or more full-term pregnancies, use of oral contraceptives, and possibly tubal ligation and lactation are protective. ${ }^{38-40}$ Several studies of ovarian cancer have examined possible associations with endogenous estrogens, hormone replacement therapy, various dietary factors, and other purported risk factors, but results to date have been inconsistent. ${ }^{36,41}$ Results from a recent cohort mortality study suggest that hormone replacement therapy of long duration may modestly increase risk. $^{42}$

Although the focus of this review is on glutathione $S$-transferase polymorphisms, we briefly summarize here major genes that have been implicated in some cases of ovarian cancer. Hereditary ovarian cancer due to BRCA1 or BRCA2 gene mutations accounts for roughly $5 \%$ to $11.7 \%$ of all cases of ovarian cancer. ${ }^{43-45}$ Women carrying germline mutations in BRCA1 or $B R C A 2$ have a high lifetime risk of developing breast and/or ovarian cancer. ${ }^{43}$ Other genetic syndromes that may include ovarian cancer as an associated feature include Peutz-Jeghers syndrome, multiple endocrine neoplasia type 1 (MEN1), and hereditary nonpolyposis colon cancer (HNPCC). ${ }^{46,47}$ Germline mutations in the LKB1 gene are associated with PeutzJeghers syndrome. ${ }^{46}$ Mutations of $M L H 1$ and $M S H 2$ have been implicated in HNPCC. ${ }^{47}$ 
Table 1

Population frequency of GSTP1 polymorphisms among controls

\begin{tabular}{|c|c|c|c|c|c|c|c|c|c|}
\hline \multirow{2}{*}{$\begin{array}{l}\text { Area of study/ } \\
\text { ethnicity }\end{array}$} & \multicolumn{2}{|l|}{ Controls } & \multicolumn{3}{|c|}{ Exon $5(\operatorname{codon} 105)^{a}$} & \multicolumn{3}{|c|}{ Exon $6(\operatorname{codon} 114)^{b}$} & \multirow[b]{2}{*}{ Reference } \\
\hline & Type & $N$ & $\mathrm{~A} / \mathrm{A}$ & $\mathrm{A} / \mathrm{G}$ & $\mathrm{G} / \mathrm{G}$ & $\mathrm{A} / \mathrm{A}$ & $\mathrm{A} / \mathrm{V}$ & $\mathrm{V} / \mathrm{V}$ & \\
\hline \multicolumn{10}{|l|}{ Australia } \\
\hline Aboriginal & Convenience sample & 52 & 82 & 13 & 4 & 100 & 0 & 0 & Harris et al. ${ }^{14}$ \\
\hline Chinese & Convenience sample & 50 & 65 & 31 & 4 & 98 & 2 & 0 & \\
\hline European & Convenience sample & 199 & 40 & 51 & 9 & 85 & 15 & 0 & \\
\hline Indian & Convenience sample & 40 & 50 & 45 & 5 & 85 & 13 & 2 & \\
\hline \multicolumn{10}{|l|}{ Australia } \\
\hline Caucasian & $\begin{array}{l}\text { Females with no cancer history age matched } \\
\text { to breast cancer cases }\end{array}$ & 129 & 46 & 50 & 4 & & & & Curran et al. ${ }^{12}$ \\
\hline Australia & $\begin{array}{l}\text { Unrelated females, frequency-matched on } \\
\text { age to ovarian cases }\end{array}$ & 292 & 39 & 46 & 15 & & & & Spurdle et al. ${ }^{24}$ \\
\hline Estonia & $\begin{array}{l}\text { Unrelated volunteers without cataract, } \\
\text { glaucoma or uveitis }\end{array}$ & 202 & 43 & 45 & 13 & 79 & 21 & 0 & Juronen et al. ${ }^{16}$ \\
\hline Finland & Healthy blood donors & 293 & 53 & 38 & 9 & 82 & 17 & 0 & Saarikoski et al. ${ }^{33}$ \\
\hline $\begin{array}{l}\text { Germany } \\
\text { German } \\
\text { Austrian } \\
\text { Swiss }\end{array}$ & $\begin{array}{l}\text { Nonrelapsed acute lymphoblastic leukemia } \\
\text { patients, matched to relapsed cases on } \\
\text { sex, age at diagnosis, white blood count at } \\
\text { diagnosis, and treatment }\end{array}$ & 64 & 50 & 34 & 16 & 75 & 25 & 0 & Stanulla et al. ${ }^{25}$ \\
\hline \multicolumn{10}{|l|}{ Italy } \\
\hline Caucasian & Male coke oven workers & 70 & 56 & 34 & 10 & 91 & 7 & 1 & Viezzer et al. ${ }^{27}$ \\
\hline Japan & $\begin{array}{l}\text { Male smokers free from pulmonary disease } \\
\text { with normal function tests }\end{array}$ & 50 & 52 & 44 & 4 & 100 & 0 & 0 & Ishii et al. ${ }^{31}$ \\
\hline Japan & $\begin{array}{l}\text { Visitors of local medical clinics with no } \\
\text { previous diagnosis of cancer }\end{array}$ & 122 & 93 & 24 & 5 & & & & Katoh et al. ${ }^{17}$ \\
\hline Japan & Healthy controls & 164 & 69 & 29 & 2 & & & & Morita et al. ${ }^{32}$ \\
\hline \multicolumn{10}{|c|}{ The Netherlands } \\
\hline Caucasian & $\begin{array}{l}\text { Healthy nonpregnant female controls with } \\
\text { at least } 1 \text { uncomplicated pregnancy and } \\
\text { no spontaneous abortion }\end{array}$ & 109 & 54 & 41 & 5 & & & & Zusterzeel et al. ${ }^{30}$ \\
\hline \multicolumn{10}{|c|}{ The Netherlands } \\
\hline Caucasian & Healthy volunteers & 247 & 59 & 36 & 5 & & & & van Lieshout et al. ${ }^{26}$ \\
\hline \multicolumn{10}{|l|}{ Norway } \\
\hline Caucasian & $\begin{array}{l}\text { Healthy males matched on age and smoking } \\
\text { dose to lung cancer patients }\end{array}$ & 297 & 52 & 39 & 9 & & & & Ryberg et al. ${ }^{23}$ \\
\hline Poland & Healthy male volunteers & 170 & 49 & 44 & 7 & & & & Butkiewicz et al. ${ }^{11}$ \\
\hline \multicolumn{10}{|l|}{ Spain } \\
\hline Caucasian & Healthy volunteers & 200 & 50 & 44 & 6 & & & & Rodriguez-Frias et al. ${ }^{21}$ \\
\hline \multicolumn{10}{|l|}{ UK } \\
\hline Caucasian & Renal transplant survivors & 222 & 47 & 39 & 14 & 86 & 14 & nd & Marshall et al. ${ }^{18}$ \\
\hline \multicolumn{10}{|l|}{ UK } \\
\hline Caucasian & $\begin{array}{l}\text { Controls matched to acute leukemia cases } \\
\text { on age, gender, and ethnicity }\end{array}$ & 946 & 49 & 37 & 14 & & & & Rollinson et al. ${ }^{22}$ \\
\hline \multicolumn{10}{|l|}{ UK } \\
\hline Caucasian & $\begin{array}{l}\text { Community controls, age and sex matched } \\
\text { to CRC cases }\end{array}$ & 178 & 46 & 42 & 12 & 76 & 21 & 3 & Welfare et al. ${ }^{29}$ \\
\hline \multicolumn{10}{|l|}{ UK } \\
\hline Caucasian & $\begin{array}{l}\text { Unrelated patients without neurology } \\
\text { problems who attended the North } \\
\text { Staffordshire Hospitals }\end{array}$ & 156 & 47 & 39 & 14 & & & & Mann et al. ${ }^{19}$ \\
\hline
\end{tabular}


Table 1

Continued

\begin{tabular}{|c|c|c|c|c|c|c|c|c|c|}
\hline \multirow{2}{*}{$\begin{array}{l}\text { Area of } \\
\text { study/ethnicity }\end{array}$} & \multicolumn{2}{|l|}{ Controls } & \multicolumn{3}{|c|}{ Exon $5(\operatorname{codon} 105)^{a}$} & \multicolumn{3}{|c|}{ Exon $6(\operatorname{codon} 114)^{b}$} & \multirow[b]{2}{*}{ Reference } \\
\hline & Type & $N$ & $\mathrm{~A} / \mathrm{A}$ & $\mathrm{A} / \mathrm{G}$ & $\mathrm{G} / \mathrm{G}$ & $\mathrm{A} / \mathrm{A}$ & $\mathrm{A} / \mathrm{V}$ & $\mathrm{V} / \mathrm{V}$ & \\
\hline \multicolumn{10}{|l|}{ UK } \\
\hline Caucasian & Control individuals & 155 & 51 & 43 & 6 & & & & Harries et al. ${ }^{13}$ \\
\hline \multicolumn{10}{|l|}{ USA, MD } \\
\hline Caucasian & $\begin{array}{l}\text { Matched to breast cancer cases on age, } \\
\text { menopausal status, time since last } \\
\text { menstrual period, and date of blood } \\
\text { donation }\end{array}$ & 113 & 50 & 42 & 8 & & & & Helzlsouer et al. ${ }^{15}$ \\
\hline \multicolumn{10}{|l|}{ USA, NC } \\
\hline Caucasian & Convenience sample & 287 & 42 & 51 & 7 & 82 & 18 & 0 & Watson et al. ${ }^{28}$ \\
\hline African-American & Convenience sample & 137 & 35 & 46 & 19 & 95 & 5 & 0 & \\
\hline Taiwanese & Convenience sample & 116 & 67 & 30 & 3 & nd & nd & nd & \\
\hline \multicolumn{10}{|l|}{ USA, PA, NY } \\
\hline Caucasian & $\begin{array}{l}\text { Hospital controls matched to oral cancer } \\
\text { cases on age at diagnosis, race, and sex, } \\
\text { with no prior diagnosis of cancer, heart } \\
\text { disease, emphysema, or COPD }\end{array}$ & 163 & 39 & 53 & 9 & 85 & 14 & 1 & Park et al. ${ }^{20}$ \\
\hline African-American & & 83 & 29 & 53 & 18 & 98 & 2 & 0 & \\
\hline
\end{tabular}

nd, not determined.

${ }^{a} \mathrm{~A}$, isoleucine; $\mathrm{G}$, valine.

${ }^{b} \mathrm{~A}$, alanine; $\mathrm{V}$, valine.

\section{DISEASE ASSOCIATIONS}

The studies reviewed in this section were identified by searching MEDLINE by using the MeSH headings "ovarian neoplasms" and "glutathione transferase," and the text words "GST" and "glutathione S-transferase." Reference lists were also reviewed from published articles. Papers written in English and published between January 1993 and March 2001 were reviewed. Studies that looked at prognosis or chemoresistance were excluded. ${ }^{48-50}$

Lallas et al..$^{51}$ examined associations with GSTM1 genotype in 138 genotyped patients with epithelial ovarian cancer in Iowa and 77 unmatched controls who were paid volunteers (Table 2). Women with a family history of ovarian, breast, or colon cancer were excluded from the control group. Women who had the null GSTM1 genotype were not at increased risk of ovarian cancer ( $\mathrm{OR}=0.7$, no confidence interval given). No associations were observed between GSTM1 genotype and age at diagnosis, histological type, or stage of ovarian cancer. This study is limited by the use of volunteer controls and by the small sample size. Associations with GSTM1a and GSTM1b genotype were examined by Sarhanis et al. ${ }^{52}$ in a study involving 84 patients with epithelial ovarian cancer and 312 control patients from the same hospital in North Staffordshire. No associations were observed with the null GSTM1 genotype in comparisons with homozygosity for either the GSTM1a or GSTM1b genotypes (Table 2). The study is limited by the use of patient controls and by the small number of cases. Of 23 patients with tumors that produced or expressed $\mathrm{p} 53$ protein, 20
(87\%) were GSTM1 null. The frequency distributions of GSTM1 genotypes in p53-positive and p53-negative tumor samples were significantly different $(P=0.002)$. Hengstler et al..$^{53}$ examined associations with GSTM1 genotype in 103 patients with epithelial ovarian cancer and 115 control patients. The controls included patients from the same hospital in Mainz, Germany, and also nursing home residents. No associations were observed with the null GSTM1 genotype (OR = $0.8,95 \%$ CI $0.4-1.3)$. This study is limited by the use of patient controls and by the small sample size. GSTM1 genotype was unrelated to histological type, grade, or stage of ovarian cancer.

Different results were obtained by Baxter et al. ${ }^{54}$ in a study of 219 women with epithelial ovarian cancer who were treated at hospitals in southeast England and 219 healthy female volunteer controls who resided in the same region. The GSTM1 null genotype was more frequent among the cases than controls ( $59 \%$ vs. $49 \%, \mathrm{OR}=1.5,95 \% \mathrm{CI} 1.1-2.1)$. This study is limited by the use of patient controls and by the small sample size. After stratification by histological subtype, a significantly increased frequency of the GSTM1 null genotype was only observed for endometrioid $(65 \%, P=0.013)$ and combined endometrioid/clear cell ovarian cancers $(67 \%, P=0.004)$. Further evidence that deletion of GSTM1 may specifically increase the risk of these histological subtypes was observed by Spurdle et al. ${ }^{24}$ in a case-control study of epithelial ovarian cancer from Brisbane, Australia (285 hospitalized cases and 295 convenience controls from a twin study who were matched to the cases on age). These investigators observed no associa- 
Table 2

Summary of studies of epithelial ovarian cancer and GSTM1

\begin{tabular}{|c|c|c|c|c|c|c|c|c|c|}
\hline \multirow{2}{*}{$\begin{array}{l}\text { Area of study; } \\
\text { recruitment period }\end{array}$} & \multicolumn{2}{|l|}{ Cases } & \multicolumn{2}{|l|}{ Controls } & \multirow[b]{2}{*}{$\%$ GSTM1 null } & \multirow{2}{*}{$\begin{array}{l}\text { Variables } \\
\text { adjusted for }\end{array}$} & \multirow{2}{*}{$\begin{array}{l}\text { OR }(95 \% \mathrm{CI}) \text { for null } \\
\text { versus other genotypes }\end{array}$} & \multirow{2}{*}{$\begin{array}{l}\text { Subgroup analysis } \\
\text { reported }\end{array}$} & \multirow[b]{2}{*}{ Reference } \\
\hline & Type & $N$ & Type & $N$ & & & & & \\
\hline Iowa, US; before 1996 & $\begin{array}{l}\text { Predominately } \\
\text { Caucasian } \\
\text { patients from } \\
\text { hospital/clinic }\end{array}$ & 138 & $\begin{array}{l}\text { Caucasian volunteers } \\
\text { without a family } \\
\text { history of cancer }\end{array}$ & 77 & 58 & None & $\begin{array}{l}\text { Null versus GSTM1 } \\
\text { positive: } 0.7 \text { [CI not } \\
\text { provided] }\end{array}$ & None $^{a}$ & Lallas et al. ${ }^{51}$ \\
\hline \multirow[t]{2}{*}{$\begin{array}{l}\text { UK, North } \\
\text { Staffordshire; } \\
\text { 1993-1994 }\end{array}$} & $\begin{array}{l}\text { Caucasian } \\
\text { patients from } \\
\text { one hospital }\end{array}$ & 84 & $\begin{array}{l}\text { Unrelated Caucasian } \\
\text { patients }^{b}\end{array}$ & 312 & 62 & None & $\begin{array}{l}\text { Null versus GSTM1a } \\
\text { homozygote: } 0.9[\mathrm{CI} \\
\text { not provided] }\end{array}$ & None $^{c}$ & Sarhanis et al. ${ }^{52}$ \\
\hline & & & & & & & $\begin{array}{l}\text { Null versus GSTM1b } \\
\text { homozygote: } 0.8[\mathrm{CI} \\
\text { not provided] }\end{array}$ & & \\
\hline $\begin{array}{l}\text { Southeast UK; 1993- } \\
\quad 1998\end{array}$ & $\begin{array}{l}\text { Caucasian } \\
\text { patients from } \\
\text { hospitals }\end{array}$ & 293 & $\begin{array}{l}\text { Healthy Caucasian } \\
\text { volunteers }\end{array}$ & 219 & 49 & None & $\begin{array}{l}\text { Null versus GSTM1 } \\
\text { positive: } 1.5(1.1-2.1)\end{array}$ & Histological type $\mathrm{e}^{d}$ & Baxter et al. ${ }^{54}$ \\
\hline $\begin{array}{l}\text { Germany, Mainz; } \\
\text { 1994-1996 }\end{array}$ & $\begin{array}{l}\text { Caucasian } \\
\text { patients from } \\
\text { one hospital }\end{array}$ & 103 & $\begin{array}{l}\text { Caucasian patients } \\
\text { and nursing home } \\
\text { residents }\end{array}$ & 115 & 38 & Age & $\begin{array}{l}\text { Null versus GSTM1 } \\
\text { positive: } 0.8(0.4-1.3)\end{array}$ & $\begin{array}{l}\text { Age categories, } \\
\text { positive family } \\
\text { history of } \\
\text { cancer }^{e}\end{array}$ & Hengstler et al. ${ }^{53}$ \\
\hline $\begin{array}{l}\text { Brisbane, Australia; } \\
\text { 1985-1996 }\end{array}$ & $\begin{array}{l}\text { Predominately } \\
\text { Caucasian } \\
\text { patients from } \\
\text { one hospital }\end{array}$ & 285 & $\begin{array}{l}\text { Predominately } \\
\text { Caucasian women } \\
\text { from twin study }\end{array}$ & 297 & 55 & Age & $\begin{array}{l}\text { Null versus GSTM1 } \\
\text { positive: } 1.0(0.7-1.5)\end{array}$ & Histological type ${ }^{g}$ & Spurdle et al. ${ }^{24}$ \\
\hline
\end{tabular}

${ }^{a}$ Age at diagnosis, histological type, and stage of ovarian cancer were unrelated to GSTM1 genotype.

${ }^{b} 232$ of the patients who served as controls underwent hysterectomy and bilateral oophorectomy for benign disease (menorrhagia and pelvic inflammatory disease); other controls had benign breast disease and mild iron deficiency.

${ }^{\mathrm{p}} 53$ expression was found in 23 tumors; of these, 20 (87\%) were GSTM1 null; the frequency distributions of GSTM1 genotypes in p53-positive and p53-negative samples were significantly different $(P=0.002)$.

${ }^{d}$ A significantly increased frequency of the GSTM1 null genotype was observed for endometrioid $(65 \%, P=0.013)$ and combined endometrioid/clear cell ovarian cancers $(67 \%, P=0.004)$.

${ }^{e}$ GSTM1 null genotype was not significantly associated with histologic type, grade, or stage of epithelial ovarian cancer.

Includes 44 cases with low malignant potential and 241 invasive tumors.

${ }^{8}$ The frequency of GSTM1 variants did not vary with p53 immunohistochemical status. GSTM1 null genotype was associated with increased risk of endometrioid/ clear cell invasive cancer (age-adjusted OR $=2.0,95 \%$ CI 1.0-4.1).

tion with GSTM1 null genotype overall (age-adjusted OR = $1.0,95 \%$ CI 0.7-1.5). However, GSTM1 null genotype was associated with increased risk of endometrioid/clear cell invasive cancer (age-adjusted OR $=2.0,95 \%$ CI 1.0-4.1). Because only 32 cases with endometrioid cancer and 15 cases with clear cell carcinoma were included, the study had limited ability to look at associations within histologic subtypes of ovarian cancer.
Evidence of (positive or inverse) associations with other histological types was not observed.

Associations with GSTT1 genotype have also been examined (Table 3). Sarhanis et al. ${ }^{52}$ found no association with GSTT1 genotype in their study of 81 patients and 325 controls. Hengstler et al. ${ }^{53}$ examined associations with GSTT1 genotype in their study of 103 patients with ovarian cancer and 115 con-

Table 3

Summary of studies of epithelial ovarian cancer and GSTT1

\begin{tabular}{|c|c|c|c|c|c|c|c|c|c|}
\hline \multirow{2}{*}{$\begin{array}{l}\text { Area of study; } \\
\text { recruitment period }\end{array}$} & \multicolumn{2}{|c|}{ Cases } & \multicolumn{2}{|l|}{ Controls } & \multirow[b]{2}{*}{$\%$ GSTT1 null } & \multirow{2}{*}{$\begin{array}{l}\text { Variables } \\
\text { adjusted for }\end{array}$} & \multirow{2}{*}{$\begin{array}{l}\text { OR (95\% CI)for null } \\
\text { versus other genotypes }\end{array}$} & \multirow{2}{*}{$\begin{array}{l}\text { Subgroup analysis } \\
\text { reported }\end{array}$} & \multirow[b]{2}{*}{ Reference } \\
\hline & Type & $N$ & Type & $N$ & & & & & \\
\hline $\begin{array}{l}\text { UK, North } \\
\text { Staffordshire; } \\
\text { 1993-1994 }\end{array}$ & $\begin{array}{l}\text { Caucasian } \\
\text { patients from } \\
\text { one hospital }\end{array}$ & 81 & $\begin{array}{l}\text { Unrelated } \\
\text { Caucasian } \\
\text { patients }^{a}\end{array}$ & 325 & 19 & None & $\begin{array}{l}\text { Null versus GSTT1 } \\
\text { positive: } 0.8[\mathrm{CI} \text { not } \\
\text { provided] }\end{array}$ & None & Sarhanis et al. ${ }^{52}$ \\
\hline $\begin{array}{l}\text { Germany, Mainz; } \\
\quad \text { 1994-1996 }\end{array}$ & $\begin{array}{l}\text { Caucasian } \\
\text { patients from } \\
\text { one hospital }\end{array}$ & 103 & $\begin{array}{l}\text { Caucasian } \\
\text { patients and } \\
\text { nursing home } \\
\text { residents }\end{array}$ & 115 & 14 & Age & $\begin{array}{l}\text { Null versus GSTT1 } \\
\text { positive: } 0.9(0.4-1.9)\end{array}$ & $\begin{array}{l}\text { Age categories, } \\
\text { positive family } \\
\text { history of } \\
\text { cancer }^{b}\end{array}$ & Hengstler et al..$^{53}$ \\
\hline $\begin{array}{l}\text { Brisbane, Australia; } \\
\text { 1985-1996 }\end{array}$ & $\begin{array}{l}\text { Predominately } \\
\text { Caucasian } \\
\text { patients from } \\
\text { one hospital }\end{array}$ & 285 & $\begin{array}{l}\text { Predominately } \\
\text { Caucasian } \\
\text { women from } \\
\text { twin study }\end{array}$ & 295 & 19 & Age & $\begin{array}{l}\text { Null versus GSTT1 } \\
\text { positive: } 1.1(0.7-1.6)\end{array}$ & Histological type ${ }^{c}$ & Spurdle et al. ${ }^{24}$ \\
\hline
\end{tabular}

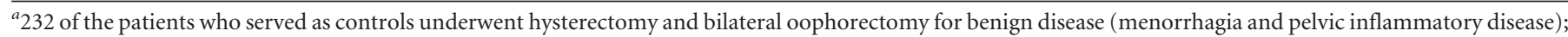
other controls had benign breast disease and mild iron deficiency.

${ }^{b}$ GSTT1 null genotype was not significantly associated with histologic type, grade, or stage of epithelial ovarian cancer.

${ }^{\circ}$ The frequency of GSTT1 variants did not vary with p53 immunohistochemical status. There was a suggestion that ovarian cancers of the endometrioid or clear cell histological subtype had a higher frequency of the GSTT1 null genotype than other histological subgroups. 
trols. No associations were observed with the null GSTT1 genotype (OR $=0.9,95 \%$ CI $0.4-1.9)$. GSTT1 genotype was unrelated to histological type, grade, or stage of ovarian cancer.

Overall, Spurdle et al. ${ }^{24}$ found no association with GSTT1 genotype (age-adjusted OR $=1.1,95 \%$ CI $0.7-1.6$ ) or with GSTP1 genotype (results not shown) in their case-control study of epithelial ovarian cancer from Brisbane, Australia. However, there was a suggestion that ovarian cancers of the endometrioid or clear cell histological subtype had a higher frequency of the GSTT1 null genotype than other histological subgroups $[P=0.04$ for comparison of endometrioid and clear cell subtypes ( $29 \%$ and $33 \%$, respectively) versus serous subtype (17\%)], but the differences were not statistically significant overall.

With respect to limitations of existing studies that should be overcome in future research, and gaps in the current epidemiologic knowledge base, only one study has looked for an association with GSTP1 genotype. In addition, reported studies of GSTM1, GSTT1, and GSTP1 and epithelial ovarian cancer have only been carried out among Caucasian populations. Studies that involve other racial and ethnic populations are needed. Furthermore, existing studies have often been based upon patient controls and hospital-based study designs. Studies with a population-based case-control study design are needed, because the latter design is more likely to be scientifically valid. Future studies of GSTM1, GSTT1, and GSTP1 and epithelial ovarian cancer should have a larger sample size with adequate numbers of incident cases and population controls, and they should be carried out in diverse populations. Gene-environment interactions, such as possible interactive effects between exogenous hormones and genotype, have not been examined in reported studies. Such interactions should be examined in future studies. A further gap in the existing knowledge base is that few studies have investigated the combined effect of polymorphic alleles in different genes on ovarian cancer risk, as discussed below.

Although results of studies carried out to date do not confirm associations between GSTM1, GSTT1, and GSTP1 and epithelial ovarian cancer, the associations are biologically plausible because glutathione $S$-transferases metabolize exogenous and endogenous substances that may have a role in ovarian cancer carcinogenesis. ${ }^{50,52}$ Studies that examine associations within specific histologic types of ovarian cancer are a promising area for further research.

\section{INTERACTIONS}

Spurdle et al. ${ }^{24}$ analyzed the combined effect of the GSTM1 and GSTT1 genotypes. The combination of the GSTM1 null and GSTT1 null genotypes resulted in an age-adjusted odds ratio of 1.1 (95\% CI 0.6-2.0), compared with the GSTM1 positive and GSTT1 positive genotypes. Similarly, no association was observed with having all three genotypes hypothesized to increase risk of ovarian cancer (GSTM1 null, GSTT1 null, and GSTP1 GG/AG; age-adjusted $\mathrm{OR}=0.8,95 \% \mathrm{CI} 0.4-1.9)$. In comparisons of endometrioid/clear cell cases and controls, however, the age-ad- justed odds ratio was 3.9 (95\% CI 1.4-11.1) for GSTM1 null combined with GSTT1 null $(P=0.01)$, compared with the GSTM1 positive and GSTT1 positive genotypes.

We did not identify any published studies that evaluated gene-environment interactions and risk of ovarian cancer.

\section{LABORATORY TESTS}

Molecular methods for determining GSTM1 and GSTT1 null genotype were summarized by Cotton et al. ${ }^{8}$ All of the studies reviewed here extracted genomic DNA from blood samples and genotyping methods used in these studies were consistent with standard techniques employed for PCR and PCR-restriction fragment length polymorphisms.

\section{POPULATION TESTING}

There is insufficient evidence associating GSTM1, GSTT1, or GSTP1 with ovarian cancer for population testing to be considered. More evidence is needed from molecular epidemiology studies to assess the causality of the associations with ovarian cancer.

\section{References}

1. Smith G, Stanley LA, Sim E, Strange RC, Wolf CR. Metabolic polymorphisms and cancer susceptibility. Cancer Surv 1995;25:27-65.

2. d'Errico A, Taioli E, Chen X. Genetic metabolic polymorphisms and the risk of cancer: a review of the literature. Biomarkers 1996;1:149-173.

3. Rebbeck TR. Molecular epidemiology of the human glutathione S-transferase genotypes GSTM1 and GSTT1 in cancer susceptibility. Cancer Epidemiol Biomarkers Prev 1997;6:733-743.

4. Board PG, Baker RT, Chelvanayagam G, Jermiin LS. Zeta, a novel class of glutathione transferases in a range of species from plants to humans. Biochem J 1997;328:929-935.

5. Blackburn AC, Woollatt E, Sutherland GR, Board PG. Characterization and chromosome location of the gene GSTZ1 encoding the human Zeta class glutathione transferase and maleylacetoacetate isomerase. Cytogenet Cell Genet 1998;83:109-114.

6. Board PG, Coggan M, Chelvanayagam G, Easteal S, Jermiin LS, Schulte GK. Danley DE, Hoth LR, Griffor MC, Kamath AV, Rosner MH, Chrunyk BA, Perregaux DE, Gabel CA, Geoghegan KF, Pandit J. Identification, characterization, and crystal structure of the Omega class glutathione transferases. J Biol Chem 2000;275:24798-24806.

7. Strange RC, Fryer AA. Chapter 19. The glutathine S-transferases: influence of polymorphism on cancer susceptibility. IARC Sci Publ 1999;148:231-249.

8. Cotton SC, Sharp L, Little J, Brockton N. Glutathione $S$ transferase polymorphisms and colorectal cancer. Am J Epidemiol 2000;151:7-32 [http://www.cdc.gov/genomics/hugenet/reviews/glutathione.htm].

9. Ali-Osman F, Akande O, Antoun G, Mao J-X, Buolamwini J. Molecular cloning, characterization, and expression in Escherichia coli of full-length cDNAs of three human glutathione S-transferase pi gene variants. J Biol Chem 1997;272:10004-10012.

10. Geisler SA, Olshan AF. GSTM1, GSTT1 and risk of squamous cell carcinoma of the head and neck. Am J Epidemiol 2001;154:95-105 [http://www.cdc.gov/genomics/ hugenet/reviews/carcinoma.htm].

11. Butkiewicz D, Grzybowska E, Phillips DH, Hemminki K, Chorazy M. Polymorphisms of the GSTP1 and GSTM1 genes and PAH-DAN adducts in human mononuclear white blood cells. Environ Mol Mutagen 2000;35:99-105.

12. Curran JE, Weinstein SR, Griffiths LR. Polymorphisms of glutathione S-transferase genes (GSTM1, GSTP1, and GSTT1) and breast cancer susceptibility. Cancer Lett 2000;153:113-120.

13. Harries LW, Stubbins MJ, Forman D, Howard GC, Wolf CR. Identification of genetic polymorphisms at the glutathione $S$-transferase Pi locus and association with susceptibility to bladder, testicular and prostate cancer. Carcinogenesis 1997;18:641-644.

14. Harris MJ, Coggan M, Langton L, Wilson SR, Board PG. Polymorphism of the Pi class glutathione $S$-transferase in normal populations and cancer patients. Pharmacogenetics 1998;8:27-31.

15. Helzlsouer KJ, Selmin O, Huang H-Y, Strickland PT, Hoffman S, Alberg AJ, Watson M, Comstock GW, Bell D. Association between glutathione S-transferase M1, P1, 
and $\mathrm{T} 1$ genetic polymorphisms and development of breast cancer. J Natl Cancer Inst 1998;90:512-518.

16. Juronen E, Tasa G, Veromann S, Parts L, Tiidla A, Pulges R, Panov A, Soovere L, Koka K, Mikelsaar A-V. Polymorphic glutathione S-transferases as genetic risk factors for senile cortical cataract in Estonians. Invest Ophthalmol Vis Sci 2000;41:2262-2267.

17. Katoh T, Kaneko S, Takasawa S, Nagata N, Inatomi H, Ikemura K, Itoh H, Matsumoto T, Kawamoto T, Bell DA. Human glutathione $S$-transferase $\mathrm{P} 1$ polymorphism and susceptibility to smoking related epithelial cancer: oral, lung, gastric, colorectal, and urothelial cancer. Pharmacogenetics 1999;9:165-169.

18. Marshall SE, Bordea C, Haldar NA, Mullighan CG, Wojnarowska F, Morris PJ, Welsh KI. Glutathione $S$-transferase polymorphisms and skin cancer after renal transplantation. Kidney Int 2000;58:2186-2193.

19. Mann CLA, Davies MB, Boggild MD, Alldersea J, Fryer AA, Jones PW, Ko CK, Young C, Strange RC, Hawkins CP. Glutathione $S$-transferase polymorphisms in MS: their relationship to disability. Neurology 2000;54:552-557.

20. Park JY, Schantz SP, Stern JC, Kaur T, Lazarus P. Association between glutatione $S$-transferase $\pi$ genetic polymorphisms and oral cancer risk. Pharmacogenetics 1999; 9:497-504.

21. Rodriguez-Frias F, Gonzalez C, Costa X, Campos F, Cotrina M, Jardi R, Miravitlles M, Vidal R. Screening for polymorphisms in exon 5 of the glutatione $S$-transferase P1 gene. Thorax 2000;55:535-536.

22. Rollinson S, Roddam P, Kane E, Roman E, Cartwright R, Jack A, Morgan GJ. Polymorphic variation within the glutathione $S$-transferase genes and risk of adult acute leukaemia. Carcinogenesis 2000;21:43-47.

23. Ryberg D, Skaug V, Hewer A, Phillips DH, Harries LW, WolfCR, Ogreid D, Ulvik A, Vu $\mathrm{P}$, Haugen A. Genotypes of glutathione transferase $\mathrm{Ml}$ and $\mathrm{P} 1$ and their significance for lung DNA adduct levels and cancer risk. Carcinogenesis 1997;7:1285-1289.

24. Spurdle AB, Webb PM, Purdie D, Chen X, Green A, Chenevix-Trench G. Polymorphisms at the glutathione $S$-transferase GSTM1, GSTT1 and GSTP1 loci: risk of ovarian cancer by histological subtype. Carcinogenesis 2001;22:67-72.

25. Stanulla M, Schrappe M, Brechlin AM, Zimmermann M, Welte K. Polymorphisms within glutatione $S$ transferase genes (GSTM1, GSTT1, GSTP1) and risk of relapse in childhood B-cell precursor acute lymphoblastic leukemia: a case-control study. Blood 2000;95:1222-1228.

26. van Lieshout EMM, Roelofs HMJ, Dekker S, Mulder CJ, Wobbes T, Jansen JB, Peters WH. Polymorphic expression of the glutathione $S$-transferase P1 gene and its susceptibility to Barrett's esophagus and esophageal carcinoma. Cancer Res 1999;59:586-589.

27. Viezzer C, Norppa H, Clonfero E, Gabbani G, Mastrangelo G, Hirvonen A, Celotti L. Influence of GSTM1, GSTT1, GSTP1, and EPHX gene polymorphisms on DNA adduct level and HPRT mutant frequency in coke-oven workers. Mutat Res 1999; 431:259-269.

28. Watson MA, Stewart RK, Smith GBJ, Massey TE, Bell DA. Human glutathione $S$-transferase P1 polymorphisms: relationship to lung tissue enzyme activity and population frequency distribution. Carcinogenesis 1998;19:275-280.

29. Welfare M, Adeokun AM, Bassendine MF, Daly AK. Polymorphisms in GSTP1, GSTPM1, and GSTT1 and susceptibility to colorectal cancer. Cancer Epidemiol Biomarkers Prev 1999;8:289-292.

30. Zusterzeel PLM, Visser W, Peters WHM, Merkus HWM, Nelen WLD, Steegers EAP. Polymorphism in the glutathione $S$-transferase P1 gene and risk of preeclampsia. Obstet Gynecol 2000;96:50-54.

31. Ishii T, Matsuse T, Teramoto S, Matsui H, Miyao M, Hosoi T, Takahashi H, Fukuchi Y, Ouchi Y. Glutathione S-transferase P1 (GSTP1) polymorphism in patients with chronic obstructive pulmonary disease. Thorax 1999;54:693-696.

32. Morita S, Yano M, Tsujinaka T, Ogawa A, Taniguchi M, Kaneko K, Shiozaki H, Doki Y, Inoue M, Morden M. Association between genetic polymorphisms of glutathione $S$-transferase P1 and N-acetyltransferase 2 and susceptibility to squamous-cell carcinoma of the esophagus. Int J Cancer 1998;79:517-520.

33. Saarikoski ST, Voho A, Reinikainen M, Anttila S, Karjalainen A, Malaveille C, Vainio H, Husgafvel-Pursiainen K, Hirvonen A. Combined effect of polymorphic GST genes on individual susceptibility to lung cancer. Int J Cancer 1998;77:516-521.

34. Cancer Facts and Figures. New York: American Cancer Society, Inc., 2002.
35. Miller BA, Kolonel LN, Bernstein L, Young JL, Swanson GM, West D, Key CR, Liff JM, Glover CS, Alexander GA, et al. (editors). Racial/ethnic patterns of cancer in the United States 1988-1992, National Cancer Institute. NIH Pub. No. 96-4104. Bethesda, MD, 1996.

36. Weiss NS, Cook LS, Farrow DC, Rosenblatt KA. Ovarian cancer. In: Schottenfeld D, Fraumeni JF, editors. Cancer epidemiology and prevention. New York: Oxford, 1996:1040-1057.

37. Tortolero-Luna G, Mitchell MF, Rhodes-Morris HE. Epidemiology and screening of ovarian cancer. Obstet Gynecol North Am 1994;21:1-23.

38. Whittemore AS, Harris R, Itnyre J, and the Collaborative Ovarian Cancer Group. Characteristics relating to ovarian cancer risk: collaborative analysis of 12 US casecontrol studies. II. Invasive epithelial ovarian cancer in white women. Am J Epidemiol 1992;136:1184-1203.

39. Daly M, Obrams GI. Epidemiology and risk assessment for ovarian cancer. Semin Oncol 1998;25:255-264.

40. Kelsey JL, Whittemore AS. Epidemiology and primary prevention of cancers of the breast, endometrium, and ovary: a brief overview. Ann Epidemiol 1994;4:89-95.

41. Coughlin SS, Giustozzi A, Smith SJ, Lee NC. A meta-analysis of estrogen replacement therapy and risk of epithelial ovarian cancer. J Clin Epidemiol 2000;53:367-375.

42. Rodriguez C, Patel A, Calle EE, Jacob EJ, Thun MJ. Estrogen replacement therapy and ovarian cancer mortality in a large prospective study of US women. JAMA 2001;285:1460-1465.

43. Risch HA, McLaughlin JR, Cole EC, Rosen B, Bradley L, Kwan E, Jack E, Vesprini DJ, Kuperstein G, Abrahamson JL, Fan I, Wong B, Narod SA. Prevalence and penetrance of germline BRCA1 and BRCA2 mutations in a population series of 649 women with ovarian cancer. Am J Hum Genet 2001;68:700-710.

44. Takahashi H, Behbakht K, McGovern PE, Chiu HC, Couch FJ, Weber BL, Friedman LS, King MC, Furusato M, LiVolsi VA. Mutation analysis of the BRCA1 gene in ovarian cancers. Cancer Res 1995;55:2998-3002.

45. Takahashi H, Chiu H-C, Bandera CA, Behbakht K, Liu PC, Couch FJ, Weber BL, LiVolsi VA, Furusato M, Rebane BA, Cardonick A, Benjamin I, Morgan MA, King SA, Mikuta JJ, Rubin SC, Boyd J. Mutations of the BRCA2 gene in ovarian carcinomas. Cancer Res 1996;56:2738-2741.

46. Wang ZJ, Churchman M, Campbell IG, Xu WH, Yan ZY, McCluggage WG, Foulkes WD, Tomlinson IP. Allele loss and mutation screen at the Peutz-Jeghers (LKB1) locus (19p13.3) in sporadic ovarian cancers. Br J Cancer 1999;80:70-72.

47. Ichikawa Y, Lemon SJ, Wang S, Franklin B, Watson P, Knezetic JA, Bewtra C, Lynch HT. Microsatellite instability and expression of MLH1 and MSH2 in normal and malignant endometrial and ovarian epithelium in hereditary nonpolyposis colorectal cancer family members. Cancer Genet Cytogenet 1999;112:2-8.

48. Howells RE, Holland T, Dhar KK, Redman CW, Hand P, Hoban PR, Jones PW, Fryer AA, Strange RC. Glutathione $S$-transferase GSTM1 and GSTT1 genotypes in ovarian cancer: association with p53 expression and survival. Int J Gynecol Cancer 2001;11:107-112.

49. Ghalia AA, Rabboh NA, el Shalakani A, Seada L, Khalifa A. Estimation of glutathione $S$-transferase and its Pi isoenzyme in tumor tissues and sera of patients with ovarian cancer. Anticancer Res 2000;20(2B):1229-1235.

50. Ferrandina G, Scambia G, Damia G, Tagliabue G, Fagotti A, Bendedetti PP, Mangioni C, Mancuso S, D'Incalci M. Glutathione $S$-transferase activity in epithelial ovarian cancer: association with response to chemotherapy and disease outcome. Ann Oncol 1997;8:343-350.

51. Lallas TA, McClain SK, Shahin MS, Buller RE. The glutathione S-transferase M1 genotype in ovarian cancer. Cancer Epidemiol Biomarkers Prev 2000;9:587-590.

52. Sarhanis P, Redman C, Perrett C, Brannigan K, Clayton RN, Hand P, Musgrove C, Suarez V, Jones P, Fryer AA, Farrell WE, Strange RC. Epithelial ovarian cancer: influence of polymorphism at the glutathione $S$-transferase GSTM1 and GSTT1 loci on p53 expression. Br J Cancer 1996;74:1757-1761.

53. Hengstler JG, Kett A, Arand M, Oesch-Bartlomowicz B, Oesch F, Pilch H, Tanner B. Glutathione $S$-transferase $\mathrm{T} 1$, and M1 gene defects in ovarian carcinoma. Cancer Letters 1998;130:43-48.

54. Baxter SW, Thomas EJ, Campbell IG. GSTM1 null polymorphism and susceptibility to endometriosis and ovarian cancer. Carcinogenesis 2001;22:63-66.

\section{APPENDIX}

\section{Internet Sites}

Data on ovarian cancer frequency

- IARC: http://www-dep.iarc.fr/

- SEER: http://www-seer.ims.nci.nih.gov/

- American Cancer Society: http://www.cancer.org/ 
General information on ovarian cancer

- National Cancer Institute: http://cancernet.nci.nih.gov/

- American Cancer Society: http://www.cancer.org/

Gene-specific information

GSTM1

- Human Gene Mutation Database: http://archive.uwcm.ac.uk/uwcm/mg/search/120020.html

- OMIM: http://www.ncbi.nlm.nih.gov/htbin-post/Omim/dispmim?138350\#TEXT

- UniGene: http://www.ncbi.nlm.nih.gov/UniGene/clust.cgi?ORG=Hs\&CID=5233

- GeneCards: http://bioinfo.weizmann.ac.il/cards-bin/carddisp?GSTM1\&search=gstm1\&suff=txt

\section{GSTT1}

- Human Gene Mutation Database: http://archive.uwcm.ac.uk/uwcm/mg/search/371704.html

- OMIM: http://www.ncbi.nlm.nih.gov/htbin-post/Omim/dispmim?600436

- UniGene: http://www.ncbi.nlm.nih.gov/UniGene/query.cgi

- GeneCards: http://bioinfo.weizmann.ac.il/cards-bin/carddisp?GSTT1\&search=gstt1\&suff=txt

\section{GSTP1}

- Human Gene Mutation Database http://archive.uwcm.ac.uk/uwcm/mg/search/120024.html

- OMIM http://www.ncbi.nlm.nih.gov/htbin-post/Omim/dispmim?134660

- UniGene http://www.ncbi.nlm.nih.gov/UniGene/clust.cgi?ORG=Hs\&CID=226795

- GeneCards http://bioinfo.weizmann.ac.il/cards-bin/carddisp?GSTP1\&search=gstp1\&suff=txt 